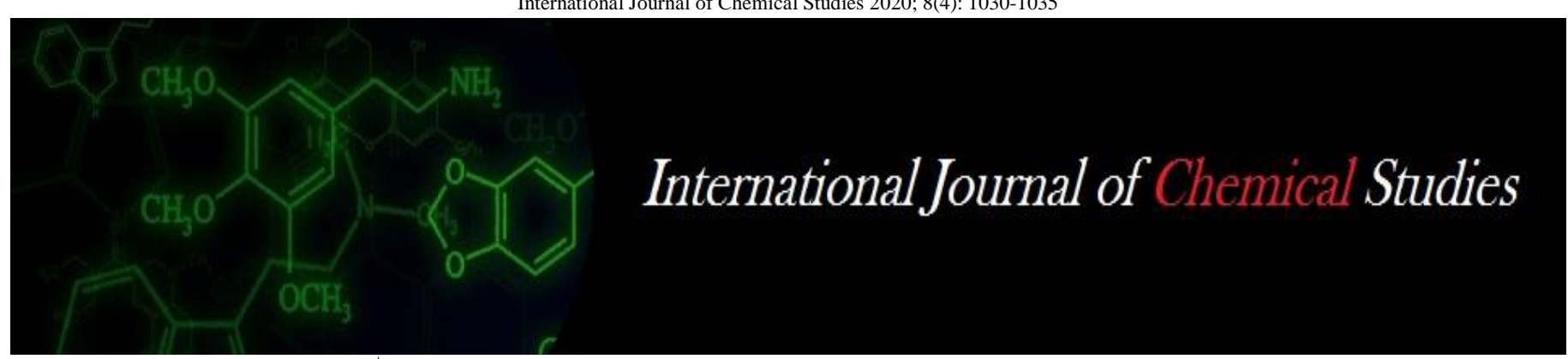

P-ISSN: 2349-8528

E-ISSN: 2321-4902

www.chemijournal.com

IJCS 2020; 8(4): 1030-1035

(C) 2020 IJCS

Received: 26-05-2020

Accepted: 28-06-2020

\section{Anitha S}

Department of Food Science \&

Technology College of

Agriculture, Hassan, Karnataka, India

\section{Ramya HN}

Department of Food Science \&

Technology College of

Agriculture, Hassan, Karnataka,

India

Ashwini A

Department of Food Science \&

Technology College of

Agriculture, Hassan, Karnataka,

India
Corresponding Author:

Anitha S

Department of Food Science \&

Technology College of

Agriculture, Hassan, Karnataka,

India

\section{Effect of mixing pumpkin powder with wheat flour on physical, nutritional and sensory characteristics of cookies}

\author{
Anitha S, Ramya HN and Ashwini A
}

DOI: https://doi.org/10.22271/chemi.2020.v8.i4g.9737

\begin{abstract}
They are usually made cookies with wheat flour which contains a limited amount of $\beta$-carotene which is a precursor of vitamin A. Pumpkin is a rich source of $\beta$-carotene, which is responsible for its yellow or orange colour. The objective of this study was to determine the optimum level of substitution of carotene rich pumpkin powder (10\%) in the formulation and to assess the quality of cookies. The prepared pumpkin powder was assessed for proximate parameters. Cookies were prepared by replacing wheat flour with pumpkin powder at different levels (viz. 10\%, and 20\%) and were assessed for their proximate, texture and sensory parameters. Pumpkin powder incorporated cookies contained $3.20 \%$ moisture, $12.43 \%$ protein, $1.99 \%$ ash, $2.79 \%$ fibre, and $36.80 \mu \mathrm{g} / 100 \mathrm{~g}$ of total carotene (on dry basis). Sensory evaluation indicated that cookies with pumpkin powder incorporated at the level of $10 \%$ was found to be more acceptable. Substitution beyond $10 \%$ affected the colour and overall acceptability of the final product. Adding pumpkin powder not only increases the nutritive value of cookies, but also brings about a value addition to pumpkin.
\end{abstract}

Keywords: Cookies, pumpkin powder, quality assessment, wheat flour, physio-chemical, sensory properties

\section{Introduction}

Wheat is the most widely cultivated cereal crop in the world and mainly used for milling and baking. Some wheat varieties (e.g. Triticum aestivum) are suitable for bread making while others (e.g. Triticum durum) are suitable for biscuits and cooking making. In recent years, bakery and confectionary products are fortified with various nutrients to enrich them to become a complete food with all necessary nutrients. The base material used for the preparation of bakery and confectionary products i.e. wheat flour contains a limited amount of $\beta$-carotene which is considered as precursor of vitamin A which is available in variety of fruits and vegetables. (Tee and Lim, 1991; Olson, 1989) ${ }^{[30,24]}$.

Wheat has been used in a variety of food products such as bread, biscuits, cakes, crackers (Lee et al., 2002; Pongjanta et al., 2006) ${ }^{[21,25]}$. Among all the bakery products, cookies which is prepared from wheat flour is more popular among the all age group population. Cookies are generally prepared from the soft wheat flour dough. Qualities of the as baking properties, color, taste and texture are more important affecting the consumer acceptance.

Pumpkins are extensively grown in tropical and subtropical countries where it traditionally consumed as freshly boiled and steamed or as a processed food items such as soup or curry. Pumpkin is high in $\beta$-carotene, which gives its yellow or orange color (Bhaskarachary et al., 2008) ${ }^{[6]}$. Incorporation of $\beta$-carotene rich foods in diets is the best measure to improve vit $A$ nutrition of individuals to overcome the problems and diseases caused by Vitamin A Deficiency (VAD) (Chandrashekhar and Kowsalya, 2002; Siems et al., 2005) ${ }^{[9,29]}$. The pumpkin powder was prepared from the flesh of pumpkin by tray drying technique in this study.

Gurung et al., $2016^{[16]}$, Physical, nutritional and sensory quality characteristics of semi -sweet type biscuit made by mixing wheat flour and pumpkin puree were studied. Wheat flour and pumpkin puree were mixed in the ratio of 100:0, 90:10, 80:20, 70:30 and 60:40. There was no significant decrease in diameter and thickness of biscuit; however bulk density increased as the amount of pumpkin increased. The nutritional quality of biscuit was positively influenced by the incorporation of pumpkin. 
Kumar Pratyush et al. $2015{ }^{[19]}$ studied on the "development and quality evaluation of pumpkin powder fortified cookies". The pumpkin powder was used for cookies preparation. It was incorporated into the traditional recipe to replace wheat flour at levels of 10, 20, 30, $40 \& 50$ in preparation. Result of sensory (appearance, colour, flavour, texture, taste and overall acceptability) evaluation revealed that the 70-30\% addition of pumpkin powder has higher overall acceptability, taste, texture and flavour and it was accepted by the panellist's.

In India, baking Industry is considered as one of the major segments of food processing sector. Baked products in the form of biscuits and cookies are gaining popularity as they offer certain advantages like availability, ready to eat convenience, cheaper than conventional snack items, availability in varieties and shelf life (Crassina et al 2012) ${ }^{[10]}$. Biscuits are ideal for nutrient availability, palatability and convenience. With the changing life style, consumers demands foods with multiple health benefits resulting in the developments of new processing technologies in food nutrition science. The present day scenario demands using of novel ingredients in commonly consumed foods rather than developing new products to improve the functional characteristics (Aleem et al. 2012) ${ }^{[2]}$

The objective of this study undertaken was to determine the optimum level of substitution of carotene rich pumpkin powder in the formulation of cookies and to assess the effect of pumpkin powder added to cookies on sensory and nutritional characteristics.

- To standardise the production of cookies made from pumpkin powder
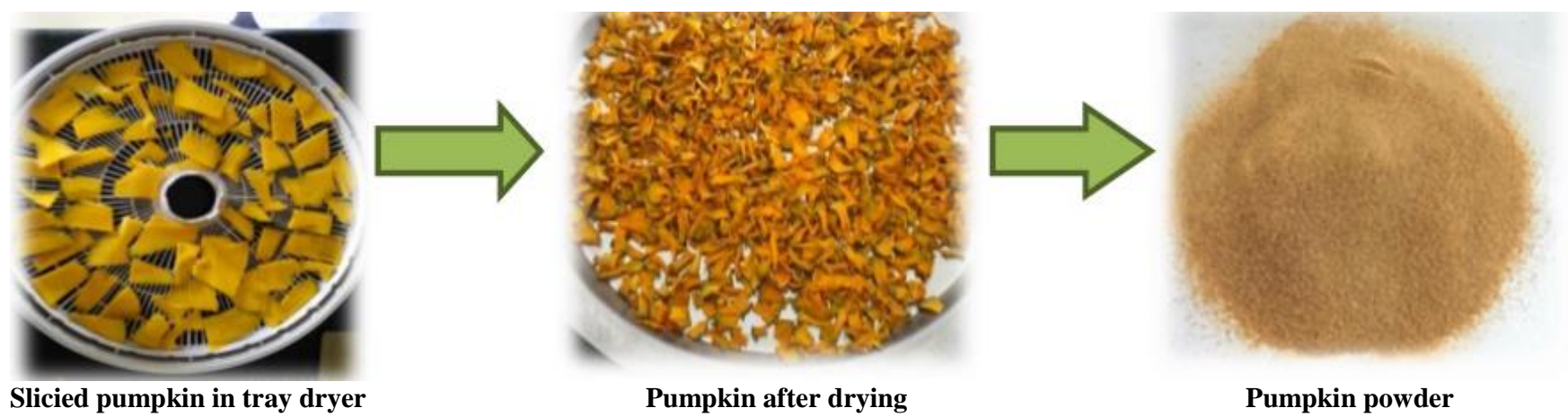

Pumpkin powder

\section{Materials and Methods} procured from the farm of Agricultural college, Hassan and Remaining ingredients such as fat, sugar powder, Vanilla essence and Baking powder for cookies were purchased from

The experiment was plan to study the effect of incorporation of different levels of three formulations were prepared by mixing wheat flour and pumpkin powder in the ratio of 100:0, 90:10 and 80:20 and coded as $T_{1}, T_{2}$ and $T_{3}$ respectively.

\section{Preparation of Pumpkin Powder}

The fresh pumpkin was washed to remove dirt and other field damaged portion with running water were peeled and the fibrous matter and seeds were removed and made into slices of $5 \mathrm{~mm}$ size cubes thickness using a vegetable slicer for pretreatments such as blanching (temperature $94^{\circ} \mathrm{C}$, time $2 \mathrm{~min}$.) and sulphitation carried out in $500 \mathrm{ppm}$ solution of potassium meta-bisulphite. The blanched sliced form of pumpkin was kept in a tray dryer for drying. Pumpkin was dried at $65^{\circ} \mathrm{C}$ for $7-8 \mathrm{hrs}$ to get desired moisture content of 5-6\%. After drying, it was grounded into powder with a mixer and sieved to get a fine powder and stored at ambient temperature conditions in sealed polythene cover for further use. the local market.

Fig 1: Flow diag/.ram for preparation of pumpkin powder

\section{Formulation and Preparation of Cookies}

The biscuits were made in the pilot bakery of Anand Agricultural University, Anand using the standard recipe consisting of refined wheat flour $100 \mathrm{~g}$, sugar $50 \mathrm{~g}$, fat $60 \mathrm{~g}$, sodium bicarbonate $0.5 \mathrm{~g}$, custard powder $2 \mathrm{~g}$ (Kamaliya an Kamaliya, 2001) ${ }^{[18]}$.

The following formulation was used for the preparation of cookies. The initial stage of recipe formulation was selection and standardization of bakery products (cookies). Various ratios of wheat flour and pumpkin powder were used to standardize the cookies. Three variations were prepared-T (Standard $100 \%$ wheat flour), $\mathrm{T}_{2}$ (wheat flour $90 \%$ and pumpkin powder $10 \%$ ), $\mathrm{T}_{3}$ (wheat flour $80 \%$ and pumpkin powder 20\%). Sugar $50 \mathrm{~g}$, Fat $50 \mathrm{~g}$, vanilla essence $0.5 \mathrm{ml}$, baking powder $0.5 \mathrm{~g}$, water $30 \mathrm{ml}$. Wheat flour (Maida), pumpkin powder, baking powder, were sieved together. Mixing- is done by 2 steps i.e shortening (Vanaspathi) and sugar powder are creamed together and the remaining ingredients such as sieved wheat flour, pumpkin powder, baking powder and vanilla essence are incorporated Finally. Mixing is followed by moulding, in which the dough is laminated into sheets and moulded into required shapes using different moulds. Moulded cookies were placed on fat greased try and Baked at $150{ }^{\circ} \mathrm{C}$ for $15 \mathrm{~min}$. After baking cookies were cooled to room temperature and packed in high density poly Ethelene covers for further chemical analysis. 


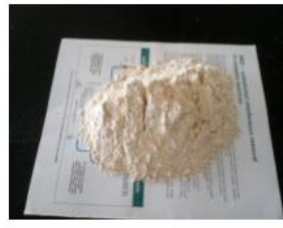

1.Weighing and Sieving

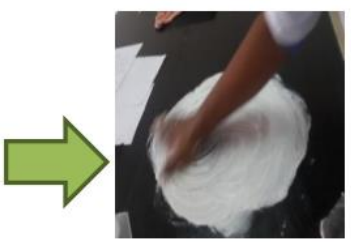

2.Creaming

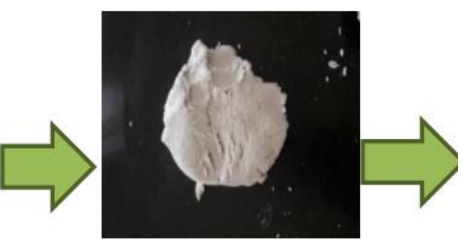

3.Dough Making

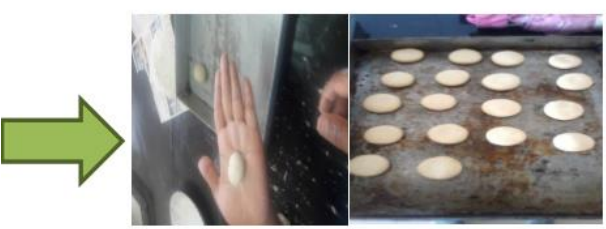

4.Moulding and Placing in trays
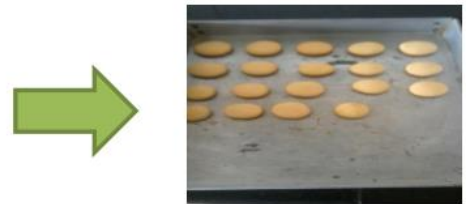

5.Baking and Cooling

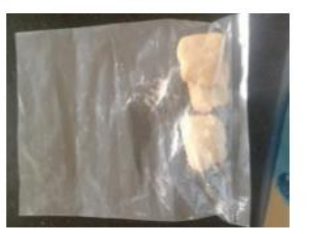

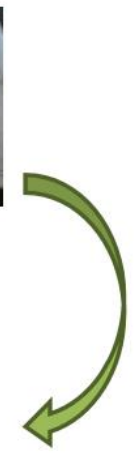

6.Packaging

Fig 2: preparation of cookies incorporated with wheat flour and pumkin powder

Table 1: Formulations used for the preparation of cookies incorporated with wheat flour and pumkin powder (percentage)

\begin{tabular}{|c|c|c|c|}
\hline Ingredients & $\mathbf{T}_{\mathbf{1}}(\mathbf{g})$ & $\mathbf{T}_{\mathbf{2}}(\mathbf{g})$ & $\mathbf{T}_{\mathbf{3}} \mathbf{( g )}$ \\
\hline Wheat Flour & 100 & 90 & 80 \\
\hline Pumpkin powder & 0 & 10 & 20 \\
\hline Fat & 50 & 50 & 50 \\
\hline Sugar powder & 50 & 50 & 50 \\
\hline Vanilla essence $(\mathrm{ml})$ & 0.5 & 0.5 & 0.5 \\
\hline Baking powder & 0.5 & 0.5 & 0.5 \\
\hline
\end{tabular}

Note:

$\mathrm{T}_{1}$ Sample $=100 \%$ wheat flour

$\mathrm{T}_{2}$ Sample $=90 \%$ wheat flour and $10 \%$ pumpkin powder

$\mathrm{T}_{3}$ Sample $=80 \%$ wheat flour and $20 \%$ pumpkin powder

\section{Sensory evaluation}

Sensory evaluation of cookies were evaluated for appearance, visual colour, flavour, taste sweetness and overall acceptability. Prepared cakes were served to the panelists in randomly with coded plates. The panel of 15 semi-trained judges using 9- point hedonic scale with 9 as like extremely and 1 as dislike extremely. The mean value of the scores is calculated.

\section{Physico-Chemical Analysis}

Moisture, protein, total ash, total dietary fibre, fat, calcium and iron contents were determined by standard methods (AOAC 2010). Total carotenoid content was estimated according to the method prescribed by Ranganna $2016^{[26]}$. Properties like thickness, diameter and spread ratio of cookies were determined as per the method described by Anu et al, $2015^{[3]}$. Spread ratio of cookies was obtained by dividing diameter by thickness of the cookies.

\section{Statistical Analysis}

Statistical Analysis was done using computer software. The analysis was done by application of ANOVA at $5 \%$ significance level.

\section{Results and Discussion \\ Proximate Analysis}

Proximate composition of pumpkin powder and wheat flour is given in the following Table II. Pumpkin powder contain highest Beta carotene (138.96/100mg), ash (7.23\%), iron $(12.0 \%)$ and Carbohydrates (82.07g). Sathiya Mala et al 2018 The pumpkin powder was found to be a good source of $\beta$ carotene. Thus, a small quantity of pumpkin powder would help alter the nutritive value of muffins to a considerable extent. The blanching and sulphitation treatments in the preparation of pumpkin powder not only helped in accelerating the drying process, but also helped in maintaining the quality of the pumpkin powder during processing and storage. This study par with our studies

Sulphitation retards browning and helps to retain the colour. The processing of vegetables has been found to increase the bio-availability of carotenoids since it breaks down cellulose structure of the plant (Vanhethoff et al., 2000) ${ }^{[31]}$.

Wheat Flour provides the structure in baked goods. Wheat flour contains proteins that interact with each other when mixed with water, forming gluten. It is this elastic gluten framework which stretches to contain the expanding leavening gases during rising. The protein content of a flour affects the strength of a dough. The different wheat flour types contain varying amounts of the gluten forming proteins.

Table 2: Nutritional Composition of Wheat flour and pumpkin powder were analysed using AOAC methods

\begin{tabular}{|c|c|c|c|c|c|c|c|c|c|c|}
\hline Ingredients & $\begin{array}{c}\text { Moisture } \\
(\%)\end{array}$ & $\begin{array}{c}\text { Protein } \\
(\%)\end{array}$ & $\begin{array}{l}\text { Fat } \\
(\%)\end{array}$ & $\begin{array}{l}\text { Ash } \\
(\%)\end{array}$ & $\begin{array}{c}\text { Fiber } \\
(\%)\end{array}$ & $\begin{array}{l}\text { Iron } \\
(\mathrm{mg})\end{array}$ & $\begin{array}{c}\text { Carbohydrates } \\
(\mathrm{g})\end{array}$ & $\begin{array}{c}\text { Vit-A ( } \begin{array}{c}\beta \text {-carotene }) \\
(\mathrm{mg})\end{array} \\
\end{array}$ & $\begin{array}{c}\text { Energy } \\
\text { (Kcal) }\end{array}$ & $\begin{array}{l}\text { Calcium } \\
\text { (mg) }\end{array}$ \\
\hline Pumpkin powder & 6.01 & 14.37 & 1.32 & 5.60 & 2.91 & 12.0 & 72.70 & 138.96 & 353.64 & 100.00 \\
\hline Wheat flour & 13.3 & 11.00 & 0.9 & 0.60 & 0.30 & 2.70 & 73.90 & 25.00 & 348.00 & 23.00 \\
\hline
\end{tabular}




\section{Sensory Analysis}

Table 3: Mean scores for the sensory evaluation of cookies samples

\begin{tabular}{|c|c|c|c|}
\hline Quality Parameters & $\mathbf{T}_{\mathbf{1}}$ & $\mathbf{T}_{\mathbf{2}}$ & $\mathbf{T}_{\mathbf{3}}$ \\
\hline Colour & 8.5 & 8.0 & 8.5 \\
\hline Aroma & 8.0 & 9.0 & 8.0 \\
\hline Appearance & 8.0 & 8.5 & 8.0 \\
\hline Taste & 8.0 & 8.5 & 7.0 \\
\hline Texture & 8.0 & 8.5 & 7.5 \\
\hline Overall acceptability & 8.5 & 9.0 & 8.0 \\
\hline
\end{tabular}

Note: $\mathrm{T}_{1}$ Sample $=100 \%$ wheat flour, $\mathrm{T}_{2}$ Sample $=90 \%$ wheat flour, $10 \%$ pumpkin powder, $\mathrm{T}_{3}$ Sample $=80 \%$ wheat flour, $20 \%$ pumpkin powder

\section{Scoring System}

9-like extremely 8-like very much 7-like moderately 6-like slightly 5-neither like nor dislike 4-dislike slightly 3-dislike moderately 2 -dislike very much 1 -dislike extremely

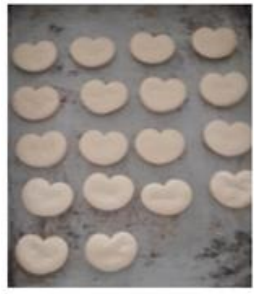

T1 Sample

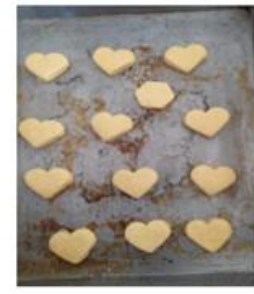

T2 Sample

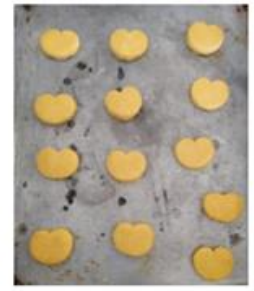

T3 Sample
Fig 3: Cookies prepared by incorporation of different levels of pumpkin powder

The mean scores for sensory evaluation of control $\left(\mathrm{T}_{1}\right), \mathrm{T}_{2}$ and $\mathrm{T}_{3}$ samples are shown in Table III. $\mathrm{T}_{2}$ containing $10 \%$ pumpkin powder and $90 \%$ wheat flour had the highest scores aroma, taste, Texture, appearance and the overall acceptability. Sample $\mathrm{T}_{3}$, containing $20 \%$ pumpkin powder and $80 \%$ wheat flour and control $\left(\mathrm{T}_{1}\right)$ as no significance difference in colour. Color development of baked products is caused by Maillard reactions between sugars and proteins. Others factors that might contribute to the color of final products were ingredients' composition, time of baking (Cronin and Preis, 2000) ${ }^{[11]}$. Hernandez-Ortega et al. (2013) ${ }^{[17]}$ report improved color of cookies with increase in the percentage of carrot pomace powder due to increase in carotenoids content.

The mean score for appearance varied from 8 to 8.5 with different levels of incorporation of pumpkin powder into cookies. It was observed that the cookies sample prepared by addition of pumpkin powder at $10 \%$ it showed highest scores for appearance. Result par with Gurung et al., $2016^{[16]}$

The mean score for taste varied from 7.0 to 8.5 with different levels of addition of pumpkin powder on cookies. It was observed that cookies prepared by replacing $10 \%$ of pumpkin powder scored the maximum (8.50) compare to $20 \%$ incorporated pumpkin powder and control. As replacement level was increased to $20 \%$ results in increase in bitterness was observed.

The mean score for texture varied from 7.5 to 8.5 the maximum and the minimum value corresponded to the samples of cookies prepared by replacing refined wheat flour with pumpkin powder at the level of $10 \%$ and $20 \%$, respectively. The sensory score for texture decreased gradually with increase in replacement level. As the level of replacement was increased from $10 \%$ to $20 \%$ the texture of the cookies became inferior due to the gradual increase in hardness. It is also evident from the data mentioned in that hardness of biscuit increased with increase in replacement level (Kulkarni, et al., 2013) ${ }^{[20]}$
It is evident from the table that addition of pumpkin powder up-to $10 \%$ has improved the acceptability of cookies and further increase in the concentration has adversely affected the texture, aroma, appearance, taste and overall acceptability. It is therefore concluded that highly acceptable cookies can be prepared using $10 \%$ pumpkin powder but addition of $20 \%$ levels of pumpkin powder significantly reduced the overall acceptance of the cookies. Same results were observed in Khan et al., 2017.Effect of pumpkin flour on the sensory quality of biscuits was carried out to find out the suitability and level of incorporation of pumpkin flour in wheat flour (Table 3). It is evident from the table that addition of pumpkin flour up-to $15 \%$ has improved the acceptability of biscuits and further increase in the concentration has adversely affected the texture, colour and overall acceptability. It is therefore concluded that highly acceptable biscuits can be prepared using $15 \%$ pumpkin flour and addition of beyond $15 \%$ levels of pumpkin flour significantly reduced the overall acceptance of the biscuits. There was no difference in taste up to incorporation of 30 parts of pumpkin puree but 40 parts incorporation result in low sensory score compare to other which might be due to increase in polyphenol content resulting in bitter taste (Lesschaeve and Nobel, 2005) ${ }^{[22]}$. The overall acceptability was found better for biscuit prepared by incorporation up to 30part pumpkin puree.

\section{Physical Properties of Cookies}

Cookies prepared using pumpkin powder $(0,10 \%)$ was evaluated for various physical parameters viz diameter, thickness and spread ratio (Table IV). It is clear from the table that with the incorporation of pumpkin powder $(10 \%)$, there was a significant increase $(p \leq 0.05)$ in thickness and decrease in diameter from 4.50 to $4.20 \mathrm{~cm}$ and spread ratio from 6.50 to $5.90 \%$

\section{Proximate Composition of Cookies Prepared With Incorporation of Pumpkin Powder}

Results revealed that substitution of pumpkin powder (10\%) significantly affected the proximate compositions of cookies. Moisture content in cookies increased with the addition of substituted pumpkin powder. However, the highest moisture content $(3.20 \%)$ was found in sample $\mathrm{T}_{2}(10 \%$ pumpkin powder), whereas the lowest amount $(2.44 \%)$ was resulted in control $\left(\mathrm{T}_{1}\right)$. Ash and protein content in cookies also increased with the addition of pumpkin powder. Hygroscopic nature of pumpkin powder is one of possible reasons behind the increase in moisture content. This result was in line with Bhat and Bhat who found higher moisture content in cakes with higher amount of pumpkin powder. Similar trend was also reported in banana cake by Eke et al., $2009^{[15]}$ (Akhter Most et al., 2016) [1].

The highest ash $(1.99 \%)$ and protein $(12.43 \%)$ were observed in sample $\mathrm{T}_{2}(10 \%$ pumpkin powder) and the lowest ash $(1.57 \%)$ and protein $(10.98 \%)$ were found in control $\left(\mathrm{T}_{1}\right)$. Higher ash and protein content in pumpkin powder resulted higher ash and protein in pumpkin cookies. Akhter Most et al., $2016^{[1]}$, also reported higher ash and protein content in cakes with the increase of pumpkin powder. Similar trends in ash and protein content in breads with pumpkin powder were observed by See et al., $2007^{[28]}$. In this research, fat content and total carbohydrate in cookies were found to be decreased with the replacement of flour (Table-V). Control sample contained highest fat content $(22.75 \%)$ and total carbohydrate $(62.26 \%)$, whereas sample $\mathrm{T}_{2}$ resulted in lowest fat content $(21.84 \%)$ and total carbohydrate $(60.54 \%)$. Low fat and carbohydrate content of pumpkin powder might be possible reason behind the 
decreasing of fat and carbohydrate content in supplemented cakes. Same results were also observed in Akhter Most et al., $2016^{[1]}$.

\section{Conclusion}

The pumpkin powder could be very well utilized to prepare the bakery products. Consumer's interest in cookies consumption has motivated researchers to develop pumpkin powder blended cookies. Incorporation of pumpkin powder at different levels resulted in changes in the nutritional, physical and sensory properties of cookies. It was clearly observed that addition of $10 \%$ of pumpkin powder had strong effects on physicochemical and organoleptic properties of cookies. This study revealed that pumpkin powder enhanced $\beta$-carotene content in the supplemented bakery product. Pumpkin powder is a rich source of $\beta$-carotene and minerals like calcium. Since the bakery products prepared from refined flour are low in vitamins, minerals and dietary fibre, pumpkin powder incorporation can enhance the nutritive value of cookies. Hence, pumpkin powder could be successfully added to prepare cookies to function as natural nutrient source with remarkable health benefits and increasing consumer acceptance.

\section{References}

1. Akhter Most. Jesmin, Amin Md. Ruhul, Mondal SC. Effect of pumpkin powder on physico-chemical properties of cake. International Research Journal of Biological Science. 2016; 5(4):1-5.

2. Aleem ZMD, Genitha TR, Syed IS. Effects of defatted soy flour incorporation on physical, sensorial and nutritional properties of biscuits. J Food Proc Technol. 2012; 3:4.

3. Anu B, Khalid G, Charanjit SR. Functional and sensory properties of cookies prepared from wheat flour supplemented with cassava and water chestnut flours. Cogent Food Agric. 2015; (1):1019815.

4. AOAC. Official methods of analysis of the Association of Official Analytical Chemists, 2010.

5. AOAC.2010. Association of Official Analytical Chemists. Official Methods of Analysis. 14th Edn., Method 930.04, Method 930.05, Method 970.64, Method 978.04. Washington D.C.

6. Bhaskarachary K, Ananthan R, Longvah, T. Carotene content of some common (cereals, pulses, vegetables, spices and condiments) and unconventional sources of plant origin. Food Chemistry. 2008; 106:85-89.

7. Bhat MA, Bhat A. Study on Physico Chemical Characteristics of Pumpkin Blended Cake. J Food Process Technol. 2013; 4(9):262.

8. Bina Gurung, Pravin Ojha, Dilip Subba. 1National College of Food Science and Technology, Kathmandu, Nepal 2Food Research Division, Nepal Agricultural Research Council, Lalitpur, Nepal 3Central Campus of Technology, Dharan, Nepal.

9. Chandrashekhar U, Kowsalya S. Provitamin A content of selected South Indian Foods by high performance liquid chromatography. Journal of Food Science and Technology. 2002; 39(2):183-187.

10. Crassina A, Sheetal G, Venkateshwara RG. Effect of native and germinated finger millet flour on rheological and sensory characteristics of biscuits. Int J Food Sci Technol. 2012; 47:2413-2420.

11. Cronin K, Pries C. A Statistical analysis of biscuit physical properties as affected by baking. Journal of Food Engineering. 2000; 46(4):217-225.
12. CSIR-Central Food Technological Research Institute, Resource Centre, Habshiguda, Uppal Road, Hyderabad500 007, India International Food Research Journal 25(3):1081-1087.

13. Effect of Mixing Pumpkin Puree with Wheat Flour on Physical, Nutritional and Sensory Characteristics of Biscuit

14. Effect of pumpkin powder incorporation on the physicochemical, sensory and nutritional characteristics of wheat flour muffins. Sathiya Mala K, Aathira P, Anjali EK, Srinivasulu K, Sulochanamma G.

15. Eke J, Achinewhu SC, Sanni L. Nutritional and Sensory Qualities of some Nigerian Cakes. Nigeria Food Journal. 2009; 26:12-17.

16. Gurung et al., J Food Sci. Technol. Nepal. Physical, nutritional and sensory quality characteristics of semi sweet type biscuit made by mixing wheat flour and pumpkin puree. 2016; 9:85-89.

17. Hernandez-Ortega M, Kissangou G, Necoechea Mondragón M, Sánchez-Pardo E, Ortiz-Moreno A. Microwave dried carrot pomace as a source of fi ber and carotenoids. Food and Nutrtion Sciences. 2013; 4(10): 10371046. DOI: 10.4236/fns.2013.410135.

18. Kamaliya MK, Kamaliya KB. Baking Science and Industries. 1st Edn. 2001, 1.

19. Kumar Pratyush, Dorcus M, Chita S. Development and quality evaluation of pumpkin powder fortified cookies. Int J Sci Eng Technol. 2015; 3:1034-1038.

20. Kulkarni AS, Joshi DC. Effect of replacement of wheat flour with pumpkin powder on textural and sensory qualities of biscuit. International Food Research Journal. 2013; 20(2):587-591.

21. Lee CH, Cho JK, Lee SJ, Koh W, Park W, Kim CH. Enhancing $\beta$-carotene content in Asian noodles by adding pumpkin powder. Cereal chemistry. 2002; 79(4):593-595.

22. Lesschaeve I, Noble AC. Polyphenols: factors infl uencing their sensory properties and their effects on food and beverage preferences. American Journal of Clinical Nutrtion. 2005; 81(1):330S-335S.

23. Lingert H. Development of the maillard reaction during food processing. In: Food processing, human nutrition and physiology". Finot PA, Aeschbacher HU, Hurrell RF, Liardon R, Birkhauser-Verlag B. (Eds.), 1990, 171-185.

24. Olson JA. Provitamin A function of carotenoids: the conversion of $\beta$-carotene into vitamin A. Journal of Nutrition, 1989; 119:105-108.

25. Pongjanta J, Naulbunrang A, Kawngdang S, Manon T, Thepjaikat T. Utilization of pumpkin powder in bakery products. Songklanakarin Journal of Science and Technology. 2006; 28(1):71-79.

26. Ranganna S. Handbook of analysis and quality control for fruit and vegetable products. Tata McGraw-Hill, New Delhi. Research Note J food Sci. Techol. Nepal. 2016; 9:(85-89), ISSN: 1816-0727.

27. Sathiya Mala K, Aathira P, Anjali EK, Srinivasulu K, Sulochanamma G. Effect of pumpkin powder incorporation on the physico-chemical, sensory and nutritional characteristics of wheat flour muffins. International Food Research Journal. 2018; 25(3):10811087

28. See EF, Wan Nadiah WA, Noor Aziah AA. PhysicoChemical and Sensory Evaluation of Breads Supplemented with Pumpkin powder. Asean Food Journal. 2007; 14:123-130. 
29. Siems S, Wiswedel I, Salerno C, Crifo C, Augustin LS, Langhans CD, Sommerberg O. $\beta$-carotene breakdown products may impair mitochondrial functions - Potential side effects of high dose $\beta$-carotene supplementation. Journal Nutritional Biochemistry. 2005; 16:385-397

30. Tee ES, Lim CL. Carotenoids composition and content of Malaysian vegetables and fruits by AOAC and HPLC methods. Food Chemistry. 1991; 41:309339.

31. Vanhethoff KH, De Boer BC, Tijburg JBM, Lucius BRHM, Zijp I, West CE, Hautvast JGAJ, Westrate JA. Carotenoids bioavailability in humans from tomatoes processed in different ways determined from the carotenoids response in triglyceride- rich lipoprotein fraction of plasma after a single consumption and in plasma after four days of consumption, Journal of Nutrition. 2000; 130:1189-1196. 